\title{
PERAN CITRA DESTINASI PADA HUBUNGAN e-WOM DENGAN MINAT KUNJUNGAN WISATAWAN DI PANTAI LOSARI, KOTA MAKASSAR
}

\author{
Vinny Corylitha Sarapang ${ }^{1 *}$, I Ketut Surata ${ }^{2}$, I Putu Utama ${ }^{3}$ \\ 1,2,3Program Studi Magister Terapan Pariwisata, Politeknik Pariwisata Bali, Bali- Indonesia \\ 1*)vinnycorylitha96@gmail.com , 2e-mail: surata@ppb.ac.id, ${ }^{3} \mathrm{e}$-mail: utama.stpbali@gmail.com
}

\begin{abstract}
The purpose of this study is to see and analyze the direct effect of e-WOM on visit intention and destination image, the direct effect of destination image on visit intention, and the indirect effect of e-WOM on visit intention through destination image. The methods of this study used a quantitative approach. Data was collected through online questionnaires with a total sample of 200 respondents. The sampling technique used is purposive accidental sampling. Data analysis used the SEM-PLS method. The results of this study showed that e-WOM has no direct effect and an insignificant positive relationship on visit intention, e-WOM has a positive and significant direct effect on destination image, destination image has a positive and significant direct effect on visit intention, and e-WOM has a positive and significant indirect effect on visit intention through destination image or destination image became a mediator between e-WOM and visit intention.
\end{abstract}

\section{ARTICLE HISTORY}

Submitted:28.09.2021

Revised:11.10.2021

Accepted:08.11.2021

Online first:05.01.2022

\section{KEYWORDS}

e-WOM,

destination image,

visit intention 


\section{Pendahuluan}

Sektor pariwisata di Indonesia telah berkontribusi memberikan pendapatan devisa negara yang cukup besar, apalagi ketika terjadi penggabungan sektor pariwisata dan ekonomi kreatif pada oktober 2019. Pariwisata danekonomi kreatif disebut industris trategis dalam membantu pertumbuhan perekonomian di Indonesia. Adanya pandemi Covid-19 yang terdeteksi di Wuhan, RRC pada tahun 2019 mengakibatkan permasalahan baru bermunculan tidak hanya di Indonesia tetapi juga secara global. Diantaranya terjadi penurunan jumlah perjalanan wisatawan dan hilangnya lapangan perkerjaan secara global termasuk di Indonesia (unwto.org, 2021).

Kota Makassar sebagai salah satu destinasi yang ditetapkan sebagai zona merah pada tanggal 6 september 2020 melalui Wiku Adisasmito selaku Jubir Satgas Covid-19. Aturan dan kebijakan mulai dibuat dan diberlakukan yakni menerapkan PSBB di Kota Makassar seperti penutupan tempat wisata dan pusat keramaian, membatasi jam operasional tempat usaha, hingga memperketat pengawasan pintu masuk Kota Makassar dilandaskan SK Menteri Kesehatan No HK. 01.07/MENKES/257/2020. Upaya mencegah dan menyebarkan Covid-19 melalui aturan dan kebijakan yang dibuat mengindikasi adanya penurunan jumlah kunjungan wisatawan di Kota Makassar sebagai berikut.

Tabel 1: Perkembangan Jumlah Kunjungan Wisatawan di Kota Makassar Tahun 2015-2020

(Sumber: Dinas Pariwisata Kota Makassar, 2021)

\begin{tabular}{rrrrrrr}
\hline Tahun & $\begin{array}{c}\text { Wisatawan } \\
\text { Nusantara }\end{array}$ & $\begin{array}{r}\text { Perkembangan } \\
\text { Jumlah } \\
\text { Kunjungan Mancanegara } \\
\text { Wisnus }\end{array}$ & $\begin{array}{r}\text { Perkembangan } \\
\text { Kunjungan } \\
\text { Wisman }\end{array}$ & $\begin{array}{r}\text { Total } \\
\text { Kunjungan Jumlah Kunjungan } \\
\text { Wisatawan }\end{array}$ & $\begin{array}{r}\text { Perkembangan } \\
\text { Wisatawan }\end{array}$ \\
\hline 2015 & 3.771 .066 & $0 \%$ & 53.879 & $0 \%$ & 3.824 .945 & $0 \%$ \\
2016 & 4.688 .681 & $917.615(24 \%)$ & 85.644 & $31.765(59 \%)$ & 4.774 .325 & $949.380(25 \%)$ \\
2017 & 5.187 .521 & $498.840(11 \%)$ & 102.462 & $16.818(20 \%)$ & 5.289 .983 & $515.658(11 \%)$ \\
2018 & 5.461 .677 & $274.156(5 \%)$ & 105.447 & $2.985(3 \%)$ & 5.567 .124 & $277.141(5 \%)$ \\
2019 & 4.459 .447 & $-1.002 .230(-18 \%)$ & 100.147 & $-5.300(-5 \%)$ & 4.559 .594 & $-1.007 .530(-18 \%)$ \\
2020 & 1.540 .468 & $-2.918 .979(-65 \%)$ & 29.358 & $-70.789(-71 \%)$ & 1.511 .110 & $-3.048 .484(-67 \%)$ \\
\hline
\end{tabular}

Tabel 1 menampilkan terjadi peningkatan jumlah kunjungan wisatawan setiap tahunnya di Kota Makassar dari 2015-2018, namun terjadi penurunan di tahun 2019 dan 2020. Penurunan jumlah kunjungan wisatawan di Kota Makassar secara tidak langsung juga 
mempengaruhi jumlah kunjungan wisatawan di daya tarik wisata Pantai Losari yang sekaligus menjadi ikon Kota Makassar. Berdasarkan hasil wawancara penulis pada 21 Maret 2021 terhadap beberapa pedagang UMKM didapatkan keterangan bahwa pendapatan harian pedagang pisang epe', jagung bakar, bahkan pekerja di wahana air menurun hingga dibawah 50\% dari pendapatan harian sebelum terjadi pandemi Covid-19. Dipertegas lagi melalui hasil wawancara penulis dengan Ibu Neno selaku pegawai UPTD Kota Makassar pada 14 Juni 2021 bahwa selama pandemi Covid-19 Pantai Losari telah ditutup sebanyak 2 kali, diberlakukan jam batasan kunjungan hingga pukul 10 malam, meniadakan seluruh penyelenggaraan event, bahkan membatasi pintu masuk menjadi 2 saja.

Penurunan jumlah kunjungan wisawatan di Pantai Losari menyebabkan munculnya berbagai dampak negatif bagi pihak pengelola (UPTD Kota Makassar), pemerintah, stakeholder, bahkan UMKM. Beberapa amenitas di Pantai Losari mengalami kerusakan, pendapatan daerah menurun, bahkan turunnya perekonomian pedagang UMKM. Uraian pemaparan permasalahan membutuhkan solusi untuk kembali mendatangkan wisatawan di Pantai Losari. Peningkatan jumlah kunjungan wisatawan di Pantai Losari dapat terjadi jika wisatawan memiliki perasaan ingin mengunjungi lalu memustukan berkunjung ke Pantai Losari atau dengan kata lain wisatawan harus memiliki minat kunjung (Kotler dan Keller, 2014). Teori minat kunjung diartikan sama dengan minat beli, dimana semakin tinggi minat beli konsumen maka akan mengakibatkan konsumen bertindak membeli sebuah produk dan sebaliknya jika minat konsumen rendah maka akan menghentikan konsumen untuk membeli produk tersebut (Albarq, 2014:14; Yoestini dan Eva, 2007:267).

Strategi meningkatkan minat kunjungan adalah menyediakan informasi Pantai Losari semenarik mungkin melalui e-WOM dengan melibatkan pengalaman orang yang sudah berkunjung sebelumnya (Albarq, 2013). Rekomendasi atau ulasan yang diberikan kepada konsumen lain melalui platform atau dikenal e-WOM tidak diragukan dan dapat mempengaruhi minat kunjungan, dimana semakin baik komentar seseorang pada komunikasi e-WOM melalui media sosial akan menimbulkan minat kunjungan wisatawan yang tinggi (Suwarduki, 2016; Rizky dkk., 2017:95). Strategi lainnya dengan melibatkan citra destinasi pada e-WOM, dimana semakin positif citra destinasi maka semakin meningkat juga popularitas destinasi tersebut pada masyarakat (Kim et al., 2017; Paludi, 2016). 
Sumber utama informasi yang diterima calon wisatawan melalui rekomendasi maupun komentar wisatawan lain di media sosial dapat membentuk citra destinasi, sehingga sangat penting untuk diketahui sebelum mengunjungi tempat wisata yang dimaksud agar terhindar dari resiko dan dapat menjadikan calon wisatawan merasa lebih percaya diri untuk menyusun rencana perjalanan wisata (Fotis et al., 2012; Xiang dan Gretzel, 2010; Alcazar et al., 2014:162). e-WOM berpengaruh signifikan dan positif terhadap citra destinasi (Majid, 2014; Jalilvand, 2012; Torlak et al., 2014).

Komunikasi e-WOM berpengaruh positif dan signifikan terhadap minat kunjungan dan citra destinasi secara langsung, citra destinasi berpengaruh positif dan siginifikan pada minat kunjungan secara langsung, tetapi e-WOM tidak berpengaruh positif dan signifikan pada minat kunjungan melalui citra destinasi (Setiawan dkk., 2019). Terdapat pula penemuan kontradiktif yang menunjukkan e-WOM tidak berpengaruh siginifikan dan positif secara langsung pada minat kunjungan, tetapi e-WOM dapat mempengaruhi minat kunjungan wisatawan melalui citra destinasi (Torlak et al., 2014). Penemuan berbeda citra merek tidak terbukti memediasi hubungan e-WOM dengan minat beli (Kentzo dkk., 2020).

\section{Metode}

Metode penelitian yang digunakan adalah pendekatan kuantitatif dan pengumpulan data melalui kuesioner secara online. Variabel penelitian yang diteliti yaitu e-WOM $(X)$ sebagai variabel bebas, citra destinasi (Y1) sebagai variabel intervening, dan minat kunjungan (Y2) sebagai variabel terikat. Total sampel sejumlah 200 responden sesuai kisaran ukuran sampel yang baik untuk SEM yaitu 200-400 dengan model indikator antara 10-15 dan 5\% kadar kesalahan (Sarwono, 2015). Teknik pengambilan sampel menggunakan non probability sampling dengan teknik purposive sampling dan accidental sampling. Beberapa kriteria responden yang dipilih merupakan wisatawan nusantara berdomisili di Indonesia, usia minimal 17 tahun, memiliki kemampuan verbal dan non verbal yang baik, serta yang belum pernah mengunjungi Pantai Losari tetapi pernah mendapatkan informasi tentang Pantai Losari melalui media sosial. Pengukuran variabel penelitian melibatkan Skala Likert (skala 1-5), mulai dari sangat tidak setuju hingga sangat setuju. Teknik analisis yang digunakan adalah Crosstab Analysis dan metode SEM-PLS. Instrumen penelitian melibatkan kuesioner, studi kepustakaan, dan observasi. 


\section{Hasil dan Pembahasan}

Jumlah sampel sebanyak 200 responden menunjukkan 67,5\% perempuan (135 orang) dan 32,5\% laki-laki (65 orang). Sebagian besar responden berusia 17-25 tahun 52\% (104 orang), 26-35 tahun 26\% (52 orang), 36-45 tahun 10\% (20 orang), $46-55$ tahun 9,5\% (19 orang), dan $>55$ tahun 2,5\% (5 orang). Domisili responden paling banyak dari luar Pulau Sulawesi 75\% (150 orang) dan dari Pulau Sulawesi 25\% (50 orang). Pendidikan formal terakhir responden yang unggul dari S1 51\% (102 orang), SMA/SMK/MA/Sederajat 26,5\% (53 orang), S2 12\% (24 orang), Diploma (D1/D2/D3) 8,5\% (17 orang), dan S3 2\% (4 orang). Responden terbanyak berdasarkan pekerjaan dari pelajar/mahasiswa 32\% (64 orang), karyawan swasta 30,5\% (61 orang), guru/dosen 16\% (32 orang), wirausaha 9,5\% (19 orang), PNS/BUMN/BUMD 9,5\% (19 orang), dan pilihan lainnya 2,5\% (5 orang) terdiri atas 2 orang tidak bekerja dan 3 orang ibu rumah tangga. Berdasarkan tingkat pendapatan per bulan diawali dari >Rp3.500,000 33\% (66 orang), belum berpenghasilan 29,5\% (59 orang),

Rp2.500,000-Rp3.500,000 17\% (34 orang), Rp1.500,000-Rp2.500.000 12,5\% (25 orang), dan $<$ Rp1.500.000 8\% (16 orang). Intensitas responden menggunakan media sosial per hari adalah 5-8 jam 41,5\% (83 orang), 1-4 jam 38\% (76 orang), dan >8 jam 20,5\% (41 orang). Sumber informasi dominan Pantai Losari melalui media sosial terbanya didapatkan responden dari instagram 44\% (88 orang), youtube $24,5 \%$ (49 orang), facebook $14,5 \%$ (29 orang), tripadvisor $11 \%$ (22 orang), tiktok 5,5\% (11 orang), dan pilihan lainnya $0,5 \%$ (1 orang) memilih whatsapp.

Hasil crosstab analysis antara karakteristik responden terhadap minat kunjungan memperlihatkan paling banyak karakteristik responden terpilih ialah dari perempuan, berusia 17-25 tahun, pendidikan terakhir S1, pekerjaan pelajar/mahasiswa, penghasilan $>$ Rp3.500,000, berdomisili dari Luar Pulau Sulawesi, intensitas penggunaan media sosial responden 5-8 jam per hari, dan media sosial dominan yang dijadikan responden sebagai sumber informasi Pantai Losari yaitu instagram. Selain itu juga, indikatordari variabel minat kunjungan (Y2) yang paling diminati berdasarkan karakteristik responden yakni Y2.4 dipilih sebanyak 112 responden setuju tentang ketertarikan mendapat informasi biaya yang dibutuhkan ketika mengunjungi Pantai Losari. Biaya sebagai salah satu aspek penting ketika seseorang ingin mengunjungi sebuah destinasi, dalam hal ini Pantai Losari. Setiap 
rencana perjalanan hingga pembuatan paket perjalanan wisata perlu mengetahui biaya yang diperlukan supaya dapat menentukan atraksi dan fasilitas yang bisa dinikmati, berapa lama waktu yang dibutuhkan, hingga berapa banyak orang yang bisa berkunjung menyesuaikan kondisi finansial yang ada.

Tabel 2: Hasil Path Coefficient dengan Bootstrapping

(Sumber: Data diolah, 2021)

\begin{tabular}{|c|c|c|c|c|c|c|}
\hline Item & $\begin{array}{c}\text { Original } \\
\text { Sample } \\
\text { (O) }\end{array}$ & $\begin{array}{l}\text { Sample } \\
\text { (Mean) }\end{array}$ & $\begin{array}{c}\text { Standard } \\
\text { Deviatio } \\
\mathbf{n} \\
\text { (STDEV) }\end{array}$ & $\begin{array}{c}\mathrm{T} \\
\text { Statistics } \\
(\mid \mathrm{O} / \mathrm{STDE} \\
\mathrm{VI})\end{array}$ & P Values & Keterangan \\
\hline $\begin{array}{l}\text { e-WOM }(X)->\text { Minat } \\
\text { Kunjungan }\left(Y_{2}\right)\end{array}$ & 0.093 & 0.097 & 0.058 & 1.589 & 0.113 & $\begin{array}{c}\text { Tidak } \\
\text { Signifikan }\end{array}$ \\
\hline $\begin{array}{l}\text { e-WOM }(X)->\text { Citra } \\
\text { Destinasi }\left(Y_{1}\right)\end{array}$ & 0.585 & 0.590 & 0.057 & 10.344 & 0.000 & Signifikan \\
\hline $\begin{array}{l}\text { Citra Destinasi }\left(Y_{1}\right) \\
->\text { Minat Kunjungan }\left(Y_{2}\right) \\
\text { e-WOM }(X)->\text { Citra }\end{array}$ & 0.696 & 0.694 & 0.061 & 11.425 & 0.000 & Signifikan \\
\hline $\begin{array}{l}\text { Destinasi }\left(Y_{1}\right)->\text { Minat } \\
\text { Kunjungan }\left(Y_{2}\right)\end{array}$ & 0.407 & 0.409 & 0.049 & 8.311 & 0.000 & Signifikan \\
\hline
\end{tabular}

Tabel 2 menampilkan hasil jalur koefisien dengan menggunakan teknik SEM-PLS melalui prosedur bootstrapping dengan tingkat kepercayaan 95\%, batas ketidakakuratan $(\alpha)$ $5 \%=0,05$, dan nilai $\mathrm{t}$-tabel yaitu 1,96. Jika t-statistik $<1,96$ maka Ho diterima dan Ha ditolak, tetapi apabila t-statistik >1,96 maka Ho ditolak dan Ha diterima. Pertama, hasil uji menunjukkan hubungan antara e-WOM dan minat kunjungan mendapatkan hasil original sample 0,093, t-statistik 1,589 (t-statistik<t-tabel), dan $\mathrm{p}$ values $0,113(>0,05)$ sehingga dinterpretasikan bahwa e-WOM tidak berpengaruh signifikan dan positif terhadap minat kunjungan wisatawan secara langsung. Kedua, hasil uji menunjukkan hubungan antara eWOM dan citra destinasi mendapatkan hasil original sample 0,585, t-statistik 10,344 (tstatistik>t-tabel), dan $\mathrm{p}$ values $0,000(<0,05)$ sehingga dinterpretasikan bahwa e-WOM berpengaruh signifikan dan positif terhadap citra destinasi secara langsung.

Ketiga, hasil uji menunjukkan hubungan antara citra destinasi dan minat kunjungan mendapatkan hasil original sample 0,696, t-statistik 11,425 (t-statistik>t-tabel), dan p values 0,000 $(<0,05)$ sehingga dinterpretasikan bahwa citra destinasi berpengaruh signifikan dan positif terhadap minat kunjungan wisatawan secara langsung. Keempat, hasil uji menunjukkan hubungan antara e-WOM terhadap minat kunjungan melalui citra destinasi 
mendapatkan hasil original sample 0,407, t-statistik 8,311 (t-statistik>t-tabel), dan $\mathrm{p}$ values 0,000 $(<0,05)$ sehingga dinterpretasikan bahwa e-WOM berpengaruh signifikan dan positif terhadap minat kunjungan wisatawan secara tidak langsung. Citra destinasi terbukti sebagai mediator, dimana citra destinasi mampu memediasi hubungan pengaruh e-WOM terhadap minat kunjungan wisatawan.

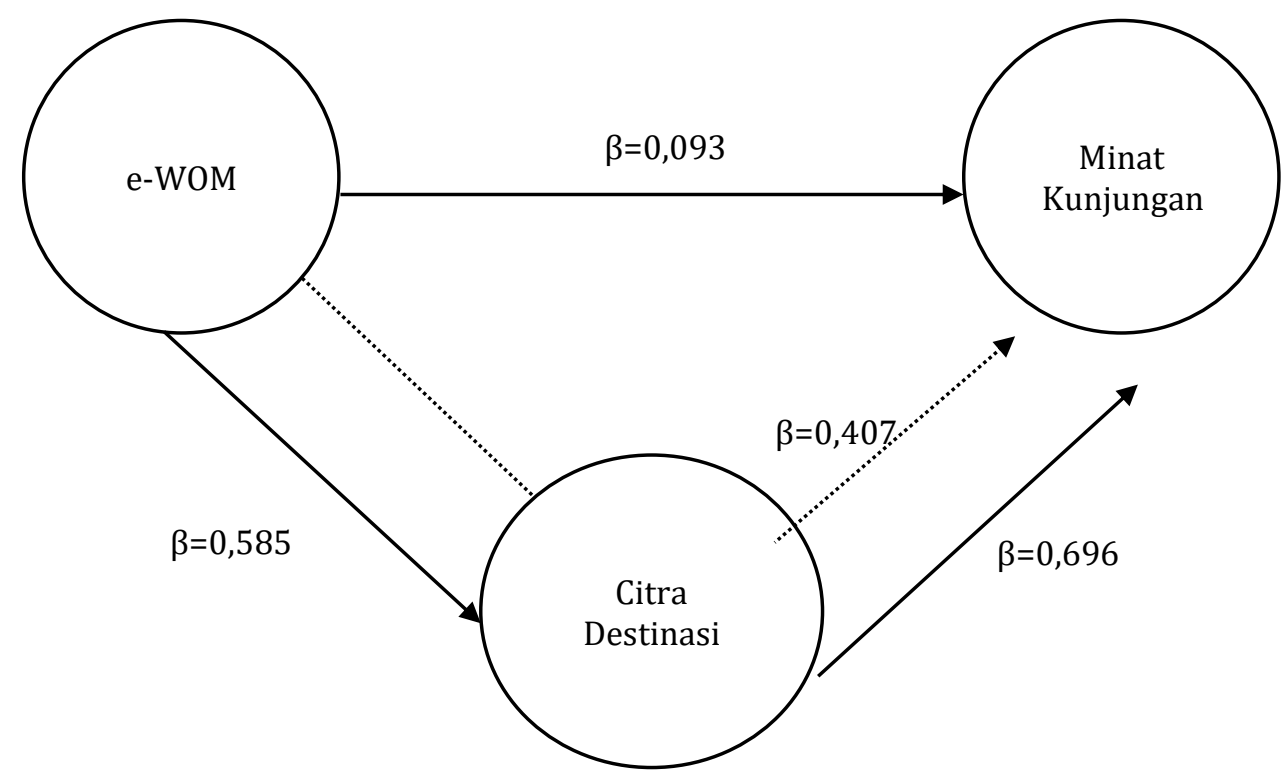

Gambar 1. Model Path Coefficient

(Sumber: Data diolah, 2021)

Hasil analisis pertama memperlihatkan tidak terdapat pengaruh signifikan dengan hubungan yang positif antara e-WOM terhadap minat kunjungan wisatawan. e-WOM sebagai bentuk komunikasi online melalui media sosial mengakibatkan sumber informasi yang disebut informan dengan penerima informasi tidak bertemu secara langsung dan dibatasi pada ulasan online seseorang atau lebih, sehingga keakuratan informasi tersebut belum terjamin (Huang et al., 2012). Kurangnya kepercayaan calon wisatawan didukung kondisi lapangan karena sejauh ini pihak pengelola Pantai Losari belum memiliki akun khusus media sosial untuk mempromosikan bahkan menginformasikan keberadaan Pantai Losari secara umum. Adanya informasi yang tersebar tentang Pantai Losari di media sosial berasal dari milik akun pribadi bukan dari instansi pengelola yang bertanggungjawab terhadap keberadaan Pantai Losari. 
Terdapat penelitian terdahulu yang hasilnya bertentangan yaitu dari Doosti dkk. (2016), Jalilvand et al. (2012), dan Setiawan dkk. (2019) yang menjelaskan e-WOM memiliki pengaruh positif langsung dan signifikan terhadap minat kunjungan wisatawan. Namun ternyata hasil penelitian sejalan juga dengan beberapa temuan penelitian terdahulu bahwa e-WOM tidak berpengaruh terhadap purchase intention atau diartikan bahwa e-WOM tidak berpengaruh signifikan dan positif terhadap minat kunjungan (Torlak et al., 2014; Saputra \& Barus, 2020; Budiono dkk., 2020). Beberapa kategori minat beli dapat diterapkan pada minat kunjung karena teori minat beli disamakan dengan teori minat kunjung (Suwarduki dkk., 2016:4). Dengan adanya temuan kontradiktif ini, maka dimungkinkan bahwa terdapat variabel lain yang menjadi pengaruh minat kunjungan yang tidak diteliti oleh penulis.

Hasil analisis kedua memperlihatkan adanya pengaruh yang signifikan dan terdapat hubungan yang positif antara e-WOM terhadap citra destinasi Pantai Losari. Keputusan hasil uji tersebut memberi gambaran bahwa informasi yang disebarkan dari mulut ke mulut secara online melalui media sosial tentang Pantai Losari mampu meyakinkan wisatawan sehingga menimbulkan persepsi tentang citra Pantai Losari. Banyaknya postingan tentang Pantai Losari dari akun-akun pribadi sebagai sumber informasi di beberapa media sosial memberikan gambaran yang berbeda-beda bagi penerimanya. Oleh sebab itu, apapun informasi melalui komunikasi e-WOM pasti berpengaruh terhadap citra destinasi tetapi tergantung dari sudut pandang penerimanya.

Arti e-WOM sendiri sebagai pernyataan yang dibuat oleh pelanggan potensial, aktual, atau bahkan mantan pelanggan secara positif maupun negatif tentang suatu produk atau perusahaan melalui internet (Thurau et al., 2004). Penjelasan tersebut diperkuat oleh pengertian citra destinasi yaitu seseorang sadar akan keberadaan sebuah tempat yang terdiri atas evaluasi kognitif dari pengalamannya, pembelajaran, emosi, maupun persepsinya (Fletcher et al., 2018:616). Pendapat hasil penelitian ini sejalan dengan beberapa studi empiris yang dilakukan oleh Setiawan (2014), Jalilvand et al. (2012), Mulyati dkk. (2018), dan Suwarduki et al. (2016) bahwa e-WOM berpengaruh positif signifikan terhadap citra destinasi. Dengan demikian, temuan ini mengartikan bahwa keberadaan e-WOM dapat mempengaruhi secara signifikan dan positif terhadap citra destinasi Pantai Losari.

Hasil analisis ketiga memperlihatkan adanya pengaruh yang signifikan dan terdapat hubungan yang positif antara citra destinasi terhadap minat kunjungan wisatawan ke Pantai 
Losari. Citra destinasi berpengaruh terhadap minat kunjungan disebabkan wisatawan memiliki persepsi sendiri dan pengetahuan terhadap citra Pantai Losari. Wisatawan akan mempertimbangkan citra Pantai Losari sebelum memiliki minat untuk berkunjung. Alasannya citra destinasi menjadi representasi dari seluruh persepsi terkait citra Pantai Losari, kemudian sebagai tujuan untuk memenuhi minat kunjungannya. Citra destinasi memang merupakan salah satu faktor yang dapat mempengaruhi pilihan wisatawan, dimana semakin positif citra destinasi maka semakin tinggi kemungkinan destinasi akan dipertimbangkan lalu dipilih (Moreira \& Iao, 2014).

Pendapat yang sama dikemukakan juga oleh Zhang et al. (2018:908) terkait citra merupakan konsep penting untuk mempengaruhi pilihan masyarakat terhadap produk, layanan, bahkan tujuannya. Banyaknya postingan citra Pantai Losari yang positif di media sosial telah mendapat respon yang baik dan berpengaruh pada minat kunjungan penerima informasi. Beberapa penelitian terdahulu terbukti mendukung dan memperlihatkan bukti terkait adanya pengaruh signifikan positif antara citra destinasi terhadap minat kunjungan seperti Jalilvand et al. (2013), Torlak et al. (2014), Mulyati dkk. (2018) dan Ryu et al. (2007). Akhirnya dapat disimpulkan bahwa temuan ini menunjukkan pentingnya keberadaan citra destinasi Pantai Losari agar dapat mempengaruhi minat kunjungan wisatawan ke Pantai Losari.

Hasil analisis keempat memperlihatkan adanya pengaruh yang signifikan dan terdapat hubungan yang positif antara e-WOM terhadap minat kunjungan wisatawan ke Pantai Losari melalui citra destinasi, bahkan citra destinasi terbukti mampu menjadi mediator bagi e-WOM terhadap minat kunjungan wisatawan. Citra Pantai Losari berperan penuh untuk menghubungkan pengaruh e-WOM terhadap minat kunjungan wisatawan, terlihat dari postingan citra Pantai Losari yang baik memberikan respon ulasan online yang positif juga. Secara tidak langsung penerima informasi tersebut menjadi berminat mengunjungi Pantai Losari. Informasi Pantai Losari dari komunikasi e-WOM akan lebih bermanfaat jika dapat menampilkan citra Pantai Losari, sehingga secara tidak langsung dapat mendorong minat seseorang untuk mengunjunginya.

Penelitian ini berimplikasi pada pengembangan konsep yang saling berkaitan yaitu eWOM, citra destinasi, dan minat kunjungan wisatawan di Pantai Losari. Hasil tersebut mendukung studi empiris yang telah ada sebelumnya dari Chew dan Jahari (2014), Jalilvand 
dan Saimei (2012), dan Setiawan dkk. (2014), dan Torlak et al. (2014) yaitu mengungkapkan citra destinasi mampu menjadi mediasi untuk pengaruh e-WOM terhadap minat kunjungan wisatawan. Temuan ini menjelaskan terkait pentingnya keberadaan e-WOM dalam menyebarluaskan informasi melalui media sosial dengan harus melibatkan citra destinasi yang positif karena nantinya dapat memberi pengaruh lebih besar khususnya dalam menarik minat kunjungan wisatawan untuk berkunjung ke Pantai Losari.

\section{Kesimpulan}

Berdasarkan hasil kajian analisis data maka dapat dikemukakan kesimpulan sebagai berikut: e-WOM tidak bepengaruh signifkan dan memiliki hubungan yang positif secara tidak langsung terhadap minat kunjungan dengan nilai $\mathrm{O}$ 0,093, t-statistik 1,589, dan $\mathrm{p}$ values 0,113 . e-WOM bepengaruh signifkan dan positif secara langsung terhadap citra destinasi dengan nilai $\mathrm{O}$ 0,585, t-statistik 10,344, dan $\mathrm{p}$ values 0,000. Citra destinasi bepengaruh signifkan dan positif secara langsung terhadap minat kunjungan dengan nilai $\mathrm{O}$ 0,696, t-statistik 11,425, dan p values 0,000. e-WOM bepengaruh signifkan dan positif secara tidak langsung terhadap minat kunjungan melalui citra destinasi dengan nilai $\mathrm{O}$ 0,407, tstatistik 8,311, dan p values 0,000 artinya citra destinasi berperan sebagai mediator antara eWOM dengan minat kunjungan. 


\section{Author's declaration}

\section{Authors' contributions and responsibilities}

Write the contribution of each author here or mark the following column.

$\sqrt{ }$ The authors made substantial contributions to the conception and design of the study.

$\sqrt{ }$ The authors took responsibility for data analysis, interpretation, and discussion of results.

$\sqrt{ }$ The authors read and approved the final manuscript.

\section{Availability of data and materials}

$\sqrt{ }$ All data are available from the authors.

\section{Competing interests}

$\sqrt{ }$ The authors declare no competing interest. 


\section{Referensi}

[1] Albarq, A.N. 2013. Measuring the Impacts of Online Word-of-Mouth on Tourists Attitude and Intentions to Visit Jordan: An Empirical Study. International Business Research, Vol.7 No.1 pp. 14-22.

[2] Albarq, Abbas N. 2014. Measuring The Impact of Online Word of Mouth On Tourists Attitude and Intention to Visit Jordan: An Empirical Study. International Business Research; Vol. 7, No. 1, 2014. http://www.emeraldinsight.com.

[3] Alcázar, M. C. H., Pinero, M. S., Maya, S. R. 2014. The effect of user-generated content on tourist behavior: the mediation role of destination image. Tourism $\mathcal{E}$ Management Studies, 10 (Special Issue). 2014. 158-164.

[4] Budiono, Gatot dkk. 2020. e-WOM Jamu Pada Konsumen Millenials (Studi Eksplanatif Brand Image dan Purchase Intention Pada Produk Jamu Indoherbal). Jurnal Nomosleca Volume 6 Nomor 2, Oktober 2020.

[5] Chang, Lung-Yu, Yu-Je Lee dan Ching-Lin Huang. 2012. The Influence of E- Word-of Mouth on The Consumer's Purchase Decision: a Case of Body Care Product. Department of Information Management, Kao Yuan University.

[6] Chew, E. Y. T., \& Jahari, S. A. 2014. Destination image as a mediator between perceived risks and revisit intention: A case of post-disaster Japan. Tourism 83 Management, 40, 382-393. https://doi.org/10.1016/j.tourman.2013.07.008.

[7] Doosti, Jalilvand, Dkk. 2015. Analyzing the influence of electronic word of mouth on visit intention: the mediating role of tourists' attitude and city image. International Journal of Tourism Cities, 137-148.

[8] Fotis, J., Buhalis, D., Rossides, N. 2012. Social Media Use and Impact during the Holiday Travel Planning Process. Information and Communication Technologies in Tourism 2012, pp. 13-24.

[9] Hennig-Thurau, T. et al., 2004. Electronic word-of-mouth via consumer-opinion platforms: What motivates consumers to articulate themselves on the Internet? Journal of Interactive Marketing, 18(1), pp.38-52.

[10] Jalilvand, M. R., \& Samiei, N. 2012. The effect of electronic word of mouth on brand image and purchase intention: An empirical study in the automobile industry in Iran. Marketing Intelligence \& Planning, Vol. 30 (4).

[11] Kentzo, dkk. 2020. Analisa Pengaruh e-WOM Terhadap Minat Beli Konsumen Setelah Kejadian Food Poisoning di Restoran X Surabaya Dengan Citra Merek Sebagai Mediator. Jurnal Hospitality \& Manajemen Jasa, Vol8, No. 1.

[12] Kim, J., Ahn, K. \& Song, H. 2017. Effects of Media and Destination Image on the Behavioral Intention to Visit Hwacheon Sancheoneo Ice Festival. International Journal of Tourism and Hospitality Research, Vol. 31 No. 4, pp 27-41, 2017.

[13] Kotler dan Keller. 2014. Buku Prinsip Prinsip Pemasaran by Philip Kotler Gary Armstrong Edisi 12 Jilid I\&2. Edisi Ke 13. Jakarta: Erlangga.

[14] Majid, Nurkholish. 2014. Analisis Pengaruh Electronic Word Mouth terhadap Brand Image dan Dampaknya pada Minat Beli Smartphone Samsung di Kota Malang.

[15] Moreira, P., \& Iao, C. 2014. A Longitudinal Study on the Factors of Destination Image, Destination Attraction and Destination Loyalty. International Journal of Social Sciences, Vol. 3 (3), 90-112.

[16] Mulyati, Yofina, Haryeni dan Masruri. 2018. Pengaruh Electronic Word of Mouth Terhadap Citra Destinasi Serta Dampaknya Pada Minat Dan Keputusan Berkunjung 
Wisatawan Domestik Pada Destinasi Wisata Kota Bukittinggi. Jurnal Ekonomi \& Bisnis Dharma Andalas Volume 20 NO 1, JANUARI 2018.

[17] Paludi, Salman. 2016. Analisis Pengaruh Electronic Word of Mouth (e-WOM) terhadap Citra Destinasi, Kepuasan Wisatawan, dan Loyalitas Destinasi Perkambungan Budaya Betawi (PBB) Setu Babakan Jakarta Selatan. https:// stein.ac.id. diakses 10 April 2021.

[18] Putu Yudi Setiawan. 2014. The Effect of e-WOM on Destination Image, Satisfaction and Loyalty. International Journal of Business and Management Invention Volume 3 Issue 1, January. 2014. http://www.ijbmi.org.

[19] Ryu, K. dan Jang, S. 2007. The effect of environmental perceptions on behavioral intentions through emotions: the case of upscale restaurants. Journal of Hospitality and Tourism Research, Vol. 31 No. 1, hlm. 56-72.

[20] Saputra, S., \& Barus, M. 2020. Pengaruh Electronic Word Of Mouth (e-Wom) Dan Citra Merek Terhadap Minat Belanja Konsumen Di Batam. Jurnal Ilmiah Manajemen dan Bisnis, Volume 5, No. 1.

[21] Sarwono, J. dan Narimawati, U. 2015. Membuat Skripsi, Tesis dan Disertasi dengan Partial Least Square SEM (PLS-SEM). Yogyakarta: Penerbit ANDI.

[22] Setiawan, H; Lestari, S; and Yanti, Devita. 2019. Keterkaitan antara Electronic Word of Mouth, Citra Destinasi, dan Minat Berkunjung ke Gunung Dempo. Jurnal Manajemen Vol. 11 (2) 2019, 143-149. http://journal.feb.unmul.ac.id/index.php/jurnalmanajemen

[23] Suwarduki Ratnaningrum Puspa, dkk. 2016. Pengaruh Electronic Word of Mouth Terhadap Citra Destinasi Serta Dampaknya Pada Minat dan Keputusan Berkunjung (Survei pada Followers Aktif Akun Instagram Indtravel yang Telah Mengunjungi Destinasi Wisata di Indonesia). UB: Malang.

[24] Torlak, Omer, Behcet Yalin Ozkara, Muhammet Ali Tiltay, Hakan Cengiz, Mehmet Fatih Dulger. 2014. The Effect of Electronic Word of Mouth on Brand Image and Purchase Intention: An Application Concerning Cell Phone Brands for Youth Consummers in Turkey. Journal of Marketing Development and Competitiveness. Vol 8 (2) 2014.

[25] Xiang, Z., \& Gretzel, U. 2010. Role of social media in Online Travel Information Search. Tourism Management.

[26] Yoestini dan Eva. S. 2007. Analisis Pengaruh Kualitas Layanan dan Citra Merek Terhadap Minat Beli dan dampaknya Pada Keputusan Pembelian. Jurnal sains Pemasaran Indonesia. No.3. Vol. VI. Hal. 261-276.

[27] Zhang, H., Wu, Y., \& Buhalis, D. 2018. A Model of Perceived Image, Memorable Tourism Experiences and Revisit Intention. Journal of Destination Marketing $\mathcal{E}$ Management, 8, 326-336. 